\title{
Manipulation of Antioxidant Status Fails to Improve Fertility of Lactating Cows or Survival of Heat-Shocked Embryos ${ }^{1}$
}

\author{
F. F. Paula-Lopes, Y. M. Al-Katanani, ${ }^{2}$ A. C. Majewski, ${ }^{3}$ \\ L. R. McDowell, and P. J. Hansen \\ Department of Animal Sciences, University of Florida \\ Gainesville, FL 32611-0910
}

\begin{abstract}
Experiments were conducted to test whether enhancement of antioxidant status could improve fertility and milk yield in dairy cows and resistance of cultured embryos to heat shock. Three experiments in three herds were performed to evaluate the effect of multiple intramuscular injections of $500 \mathrm{mg}$ of vitamin $\mathrm{E}$ and $50 \mathrm{mg}$ of selenium at 8 to $21 \mathrm{~d}$ before expected calving and at 30 and $80 \mathrm{~d}$ postpartum on reproduction of lactating Holstein cows. Vitamin E and selenium injections did not improve reproductive function or milk yield in any of the studies. The predicted 305-d milk yield (averages of least-squares means across treatments) were: 9478, 7073, and 10,204 kg projected 305-d milk for experiments 1,2 , and 3 , respectively. Percentages of cows pregnant at first service were 30,16 , and $24 \%$ in experiments 1,2 , and 3 , respectively. Three studies were performed to test whether vitamin $\mathrm{E}$ improved development of cultured bovine embryos exposed to heat shock. Heat shock of $41^{\circ} \mathrm{C}$ at the two-cell stage reduced development to the blastocyst stage, but culture with 100 $\mu M$ vitamin $\mathrm{E}$ did not reduce effects of heat shock on impaired development. For example, $9 \mathrm{~h}$ at $41^{\circ} \mathrm{C}$ reduced blastocyst development from $51.2 \pm 3.3 \%$ to 3.4 $\pm 3.3 \%$ in the absence of vitamin $\mathrm{E}$ and from $54.0 \pm$ $3.3 \%$ to $5.2 \pm 3.3 \%$ in the presence of vitamin E. Development of morulae to the blastocyst stage was not compromised by culture at $41^{\circ} \mathrm{C}$ for $9 \mathrm{~h}$. Additionally, there was no overall effect of vitamin $\mathrm{E}$ on morula development. In
\end{abstract}

Received October 16, 2002

Accepted February 19, 2003

Corresponding author: P. J. Hansen; e-mail: Hansen@animal. ufl.edu.

${ }^{1}$ This is Journal Series Number R-09161 of the Florida Agricultural Experiment Station. Research was supported in part by USDATSTAR 95-34135-1860, USDA IFAFS 2001-52101-11318 and a fellowship to Fabíola F. Paula-Lopes from CAPES, a Brazilian research funding agency.

${ }^{2}$ Present address: Department of Obstetrics \& Gynecology, University of Florida, Gainesville FL 32610.

${ }^{3}$ Present address: Department of Epidemiology and International Health, University of Alabama, Birmingham, Project San Francisco, PB 780, Kigali, Rwanda, Africa. conclusion, multiple injections of vitamin $\mathrm{E}$ and selenium at the administered levels did not improve postpartum fertility nor milk yield of lactating Holstein cows in three different herds, and there was no direct thermoprotective effect of vitamin $\mathrm{E}$ for cultured, heatshocked embryos.

(Key words: vitamin E, selenium, fertility, embryo)

Abbreviation key: $\mathbf{C O C}=$ cumulus-oocyte complexes, $\mathbf{I V F}=$ in vitro fertilization, $\mathbf{K S O M}=$ potassium simplex optimized medium, $\mathbf{S p}=$ sperm, TALP $=$ Hepes-Tyrode's albumin lactate pyruvate solution.

\section{INTRODUCTION}

Reactive oxygen species are products of natural oxygen metabolism and represent approximately 1 to $2 \%$ of metabolized oxygen (Fulbert and Cals, 1992). The balance between production and disposal of oxidant molecules is essential for tissue homeostasis. Increased rate of free radical production or decreased rate of removal leads to free radical accumulation and cellular damage (Berry and Kohen, 1999). Many antioxidant systems are present in the cell to ensure the removal of free radicals. Among these systems, glutathione peroxidase is a selenium-dependent enzyme located in the cytosol that utilizes the reducing potential of glutathione to reduce hydrogen peroxide and organic peroxides to water (Arthur, 2000). Vitamin E ( $\alpha$-tocopherol), a strong reducing agent that can give electrons to lipids undergoing peroxidation, is a major antioxidant present in plasma membranes (Wang and Quinn, 2000).

Reproductive consequences of free radical damage include disruption in function of spermatozoa (Griveau et al., 1995) and preimplantation embryos (Fujitani et al., 1997). Antioxidant status may be one determinant of reproductive function in dairy cattle. Administration of vitamin $\mathrm{E}$ or the combination of vitamin $\mathrm{E}$ and selenium has been reported to reduce the incidence of postpartum reproductive disorders such as retained fetal membranes, metritis, and cystic ovaries (Trinder et al., 1969; Harrison et al., 1984; Aréchiga et al., 1994b) and to improve fertility (Aréchiga et al., 1994b; Aréchiga et 
al., 1998b; Baldi et al., 2000). In other studies, however, there was no beneficial effect of administration of supplemental vitamin $\mathrm{E}$ alone or in combination with selenium on reproductive function (Schingoethe et al., 1982; Kappel et al., 1984; Ealy et al., 1994).

Effects of antioxidants on reproductive function may be more pronounced during heat stress because of the increased metabolic rates associated with cellular hyperthermia. Elevated temperature increases liver peroxidation (Ando et al., 1997) and activity of enzymes involved in free radical production such as xanthine oxidase (Skibba et al., 1989). Exposure of dairy cows to heat stress decreased total antioxidant activity in blood (Harmon et al., 1997). Like most cells, preimplantation embryos can produce free radicals (Yang et al., 1998). The deleterious effects of heat shock on viability of preimplantation mouse embryos can be reduced by antioxidants including vitamin $\mathrm{E}$ and glutathione (Aréchiga et al., 1994a).

The objectives of this series of studies were 1) to determine whether sequential injections of vitamin $\mathrm{E}$ and selenium at approximately $21 \mathrm{~d}$ before expected calving and 30 and $80 \mathrm{~d}$ postpartum improves reproductive function and milk yield of lactating Holstein cows under cool and hot conditions and 2) to test whether vitamin $\mathrm{E}$ improves development of in vitro-produced bovine embryos exposed to heat shock.

\section{MATERIALS AND METHODS}

\section{Materials}

Materials for the production of in vitro-derived embryos were purchased as described elsewhere (PaulaLopes and Hansen, 2002). Oocyte collection medium was Tissue Culture Medium 199 (TCM-199) with Hank's salts, without phenol red, and supplemented with $2 \%$ (vol/vol) bovine steer serum (containing $2 \mathrm{U}$ of heparin per milliliter), $100 \mathrm{U}$ of penicillin-G per milliliter, $0.1 \mathrm{mg}$ of streptomycin per milliliter, and $1 \mathrm{mM}$ glutamine. Oocyte maturation medium was TCM-199 with Earle's salts supplemented with $10 \%$ (vol/vol) steer serum, $22 \mu \mathrm{g}$ of sodium pyruvate per milliliter, $20 \mu \mathrm{g}$ of FSH per milliliter, $2 \mu \mathrm{g}$ of estradiol $17-\beta$ per milliliter, $50 \mu \mathrm{g}$ of gentamicin per milliliter, and an additional 1 $\mathrm{m} M$ glutamine. Modified Tyrode's solutions were obtained from Cell and Molecular Technologies (Lavallette, NJ) to prepare Hepes-Tyrode's albumin lactate pyruvate solution (TALP), in vitro fertilization (IVF)TALP and sperm (Sp)-TALP. Potassium Simplex Optimized Medium (KSOM) was obtained from Cell and Molecular Technologies. The KSOM, which contains 1 $\mathrm{mg}$ of BSA per milliliter, was modified on the day of use by adding an additional $2 \mathrm{mg}$ of essentially fattyacid free bovine serum albumin per milliliter, $2.5 \mu \mathrm{g}$ of gentamicin per milliliter, essential amino acids (Basal Medium Eagle) and nonessential amino acids (Minimum Essential Medium) purchased from Sigma.

A combination of vitamin $\mathrm{E}$ and selenium (MU-SE; Schering-Plough Corp., Kenilworth, NJ) was used for in vivo experiments and vitamin $\mathrm{E}[( \pm)$ - $\alpha$-tocopherol; Sigma] was used for in vitro studies. Other reagents were purchased from Fisher (Pittsburgh, PA) or Sigma (St. Louis, MO).

\section{Experiments 1 to 3: Effect of Multiple Vitamin E and Selenium Injections on Fertility of Holstein Cows}

For each experiment, cows were randomly assigned to one of two groups. Cows with odd-numbered tags received three intramuscular injections of $10 \mathrm{ml}$ of MU$\mathrm{SE}$, while cows with even-numbered tags received injections of placebo $[0.9 \%(\mathrm{wt} / \mathrm{vol}) \mathrm{NaCl}]$ at the same times. Each week for experiments 1 and 2, cows that were \pm $3 \mathrm{~d}$ of $21 \mathrm{~d}$ before expected calving received $\mathrm{Mu}$-Se or placebo. For experiment 3, cows received the first injection when they were moved to the dry cow lot by the cooperating dairy; the average interval from first injection until calving in this experiment was $16.8 \mathrm{~d}$ (standard deviation $=9.7 \mathrm{~d}$ ). For all three experiments, the other two injections were given at $\sim 30 \mathrm{~d}$ postpartum (range 27 to $33 \mathrm{~d}$ ) and $80 \mathrm{~d}$ postpartum (range 77 to 83 d). The amount of MU-SE administered was equivalent to $500 \mathrm{mg}$ vitamin $\mathrm{E}$ as D- $\alpha$ tocopheryl acetate (680 IU) and $109.5 \mathrm{mg}$ of sodium selenite (equivalent to $50 \mathrm{mg}$ of selenium). For all three experiments, birth difficulty was classified at the time of calving based on the severity of the clinical signs and the need of delivery assistance from 0 to 5 ( $0=$ not observed, $1=$ no calving difficulty, $2=$ minor problem, $3=$ needed assistance, 4 = considerable force and $5=$ very difficult).

Experiment 1 was conducted on a commercial dairy farm in Anthony, Florida $\left(29^{\circ} 17^{\prime} \mathrm{N} 82^{\circ} 07^{\prime} \mathrm{W}\right)$, using 249 Holstein cows. Estrous detection was performed based on visual observation of mounting behavior performed throughout the day and cow locomotor activity using pedometers (AFIMILK System-USA Inc., Visalia, CA). All cows were artificially inseminated after a voluntary waiting period of 90 to $120 \mathrm{~d}$ postpartum. A proportion of the cows were bred upon standing estrus, while others were bred following timed AI (Pursley et al., 1997). Cows were milked three times a day, and placed on treatment with bovine somatotropin (bST, Posilac, Monsanto, Chesterfield, MO) beginning 60 to $70 \mathrm{~d}$ postpartum and as directed by the manufacturer. Pregnancy was determined by rectal palpation at 37 to $52 \mathrm{~d}$ after insemination. Beginning $21 \mathrm{~d}$ before expected calving, cows were fed a TMR based on chopped hay 
Table 1. Frequency distribution of cows calving and first inseminations by month. ${ }^{1}$

\begin{tabular}{|c|c|c|c|c|c|c|}
\hline \multirow{2}{*}{$\begin{array}{l}\text { Month of } \\
\text { calving }\end{array}$} & \multicolumn{2}{|c|}{ Experiment 1} & \multicolumn{2}{|c|}{ Experiment 2} & \multicolumn{2}{|c|}{ Experiment 3} \\
\hline & Calving & Inseminations & Calving & Inseminations & Calving & Inseminations \\
\hline January & $0(0.0 \%)$ & $61(24.5 \%)$ & $0(0.0 \%)$ & $24(17.7 \%)$ & $1(0.3 \%)$ & $0(0.0 \%)$ \\
\hline February & $0(0.0 \%)$ & $65(26.1 \%)$ & $1(0.7 \%)$ & $16(11.8 \%)$ & $0(0.0 \%)$ & $0(0.0 \%)$ \\
\hline March & $0(0.0 \%)$ & $14(5.6 \%)$ & $1(0.7 \%)$ & $18(13.2 \%)$ & $41(13.4 \%)$ & $1(0.4 \%)$ \\
\hline April & $0(0.0 \%)$ & $1(0.4 \%)$ & $0(0.0 \%)$ & $1(0.7 \%)$ & $65(21.2 \%)$ & $0(0.0 \%)$ \\
\hline May & $2(0.80 \%)$ & $0(0.0 \%)$ & $0(0.0 \%)$ & $0(0.0 \%)$ & $101(32.9 \%)$ & $4(1.4 \%)$ \\
\hline June & $21(8.4 \%)$ & $0(0.0 \%)$ & $2(1.4 \%)$ & $1(0.7 \%)$ & $92(30.0 \%)$ & $17(6.1 \%)$ \\
\hline July & $32(12.9 \%)$ & $0(0.0 \%)$ & $10(7.3 \%)$ & $0(0.0 \%)$ & $4(1.3 \%)$ & $90(32.0 \%)$ \\
\hline August & $22(8.8 \%)$ & $0(0.0 \%)$ & $29(21.0 \%)$ & $1(0.7 \%)$ & $2(0.7 \%)$ & $77(27.4 \%)$ \\
\hline September & $66(26.5 \%)$ & $25(10.0 \%)$ & $25(18.8 \%)$ & $8(5.9 \%)$ & $1(0.3 \%)$ & $47(16.7 \%)$ \\
\hline October & $54(21.7 \%)$ & $13(5.2 \%)$ & $11(8.0 \%)$ & $30(22.1 \%)$ & $0(0.0 \%)$ & $41(14.6 \%)$ \\
\hline November & $52(20.9 \%)$ & $21(8.4 \%)$ & $37(25.8 \%)$ & $18(13.2 \%)$ & $0(0.0 \%)$ & $2(0.7 \%)$ \\
\hline December & $0(0.0 \%)$ & $49(19.7 \%)$ & $21(15.2 \%)$ & $19(14.0 \%)$ & $0(0.0 \%)$ & $2(0.7 \%)$ \\
\hline
\end{tabular}

${ }^{1}$ Data represent numbers of cows and, in parentheses, the percentage of total cows in the experiment.

formulated to provide (per cow per day) 12.0 Mcal of $\mathrm{NE}_{\mathrm{L}}, 817 \mathrm{IU}$ of vitamin $\mathrm{E}$, and $8.5 \mathrm{mg}$ of selenium. After calving, cows were fed a TMR based on corn silage and hominy formulated to provide (per day per cow) 36.0 Mcal of $\mathrm{NE}_{\mathrm{L}}$, $412 \mathrm{IU}$ of vitamin $\mathrm{E}$, and $6.3 \mathrm{mg}$ of selenium.

Experiment 2 was conducted at the University of Florida Dairy Research Unit (DRU) (Hague, Florida; $\left.29^{\circ} 46^{\prime} \mathrm{N} 82^{\circ} 25 \mathrm{~W}\right)$ using 137 Holstein cows. Estrous detection was based on visual observation of mounting behavior performed throughout the day and evaluation of chalk removal from tailheads. In addition, the majority of cows were subjected to a timed AI program (Pursley et al., 1997) for first insemination after calving. Timed AI was also used for a proportion of other inseminations. The voluntary waiting period for first insemination was $70 \mathrm{~d}$ postpartum. Cows were milked three times a day, and BST was utilized as directed by the manufacturer beginning 57 to $63 \mathrm{~d}$ postpartum. Pregnancy was determined by rectal palpation at 42 to 70 $\mathrm{d}$ after insemination. The prepartum and postpartum cows were fed a TMR based on corn silage, citrus pulp, corn meal, and alfalfa hay formulated to provide 35.2 $\mathrm{Mcal}$ of $\mathrm{NE}_{\mathrm{L}}$ per day per cow. The prepartum ration was formulated to provide (per day per cow) $530 \mathrm{IU}$ of vitamin $\mathrm{E}$ and $7 \mathrm{mg}$ of selenium, and the postpartum ration was formulated to provide (per day per cow) 350 IU of vitamin $\mathrm{E}$ and $7 \mathrm{mg}$ of selenium.

Experiment 3 was conducted on a commercial dairy farm in Bell, Florida $\left(29^{\circ} 45^{\prime} \mathrm{N} 82^{\circ} 52^{\prime} \mathrm{W}\right)$ using $307 \mathrm{Hol}-$ stein cows. Estrous detection was performed as described for experiment 1 . In addition, the majority of cows were subjected to a timed AI program (Pursley et al., 1997) for first insemination after calving; a proportion of other inseminations were also achieved using timed AI. The voluntary waiting period for insemination was $90 \mathrm{~d}$ postpartum. Cows were milked three times a day and were injected with BST as directed by the manufacturer beginning at $60 \mathrm{~d}$ postpartum. Pregnancy was determined by rectal palpation at 42 to $47 \mathrm{~d}$ after service. The prepartum cows were fed a TMR based on corn silage, wet brewers' grains and alfalfa hay formulated to provide (per day per cow) 24.9 Mcal of $\mathrm{NE}_{\mathrm{L}}, 1209 \mathrm{IU}$ of vitamin $\mathrm{E}$ and 7.5 of selenium. After calving, cows were fed a TMR based on corn silage and hominy formulated to provide (per day per cow) 38.0 Mcal of $\mathrm{NE}_{\mathrm{L}}, 1260 \mathrm{IU}$ of vitamin $\mathrm{E}$, and $14 \mathrm{mg}$ of selenium.

Table 1 shows the frequency distribution of month of calving and month of first insemination for all the three experiments. For experiments 1 and 2, most first inseminations after calving were performed during the cool months of the year. For experiment 3, the majority of cows received first insemination in warm months.

\section{Blood Collection and Analysis for Experiments 1 to 3}

Blood samples were collected at the time of first MU$\mathrm{SE}$ injection, 1 to $2 \mathrm{wk}$ after calving, and at 2 -wk intervals thereafter by venipuncture of the coccygeal vessels. Samples were collected in heparinized tubes, centrifuged for $30 \mathrm{~min}$ at $2000 \times \mathrm{g}$ at $4^{\circ} \mathrm{C}$, and plasma samples were frozen at $-20^{\circ} \mathrm{C}$ until analysis. Plasma preparation for $\alpha$-tocopherol analysis using HPLC, and the HPLC procedure were as described previously (Njeru et al., 1992). For experiment $1, \alpha$-tocopherol was determined in samples from 10 cows treated with vitamin E/selenium (41 samples) and 10 cows treated with placebo (44 samples). For experiment $2, \alpha$-tocopherol was determined for samples from 12 vitamin E/selenium treated cows (51 samples) and five cows treated with placebo (28 samples). For experiment 3, $\alpha$-tocopherol was determined for samples from five cows treated with vitamin E/selenium (17 samples) and three cows treated with placebo (nine samples). 


\section{Experiments 4 to 6: Effects of Vitamin $E$ on Susceptibility of Bovine Embryos to Heat Shock}

Procedures for in vitro production of embryos were as described earlier (Paula-Lopes and Hansen, 2002). Briefly, cumulus-oocyte complexes (COC) were obtained by slicing 2 - to $10-\mathrm{mm}$ follicles on the surface of the ovary into a beaker containing oocyte collection medium. Cumulus-oocyte complexes that had at least one layer of compact cumulus cells were washed two times and matured in groups of 10 in 50- $\mu$ l drops of oocyte maturation medium overlaid with mineral oil for $22 \mathrm{~h}$ at $38.5^{\circ} \mathrm{C}$ in an atmosphere of $5 \%$ (vol $\left./ \mathrm{vol}\right) \mathrm{CO}_{2}$ in humidified air. For fertilization, groups of $\sim 30 \mathrm{COC}$ were transferred to four well plates containing $600 \mu \mathrm{l}$ of IVF-TALP (in vitro fertilization-TALP) per well. Oocytes were fertilized with $25 \mu \mathrm{l}$ of sperm suspension and $25 \mu \mathrm{l}$ of PHE [0.5 $\mathrm{m} M$ penicillamine, $0.25 \mathrm{~m} M$ hypotaurine and $25 \mu M$ epinephrine in $0.9 \%$ (wt/vol) $\mathrm{NaCl}$ added to each well. Presumptive zygotes were removed from fertilization wells, denuded of cumulus cells, washed 2 to 3 times in Hepes-TALP to remove remaining cumulus cells and associated spermatozoa, and placed in groups of $\sim 25$ to 30 in 50- $\mu$ l drops of modified KSOM overlaid with mineral oil. Embryos at the two-cell stage were harvested at 28 to $30 \mathrm{~h}$ after insemination and morulae were collected on $\mathrm{d} 5$ after insemination.

Because vitamin $\mathrm{E}$ is hydrophobic, it was first dissolved in absolute ethanol as a $0.2 \mathrm{M}$ stock solution, stored in the dark at $4^{\circ} \mathrm{C}$, and diluted in modified KSOM to a final concentration of $100 \mu M$ vitamin $\mathrm{E}$ and 0.05 $\%$ (vol/vol) ethanol at $3 \mathrm{~h}$ before culture. Embryos were cultured in 50- $\mu$ l drops of modified KSOM containing either vehicle [0.05\% (vol/vol) ethanol] or, $100 \mu M$ vitamin $\mathrm{E}$ in $0.05 \%$ ethanol. Microdrops were overlaid with mineral oil or, when microdrops contained vitamin E, in mineral oil containing $100 \mu M$ vitamin E. Incubations were in an atmosphere of $5 \% \mathrm{CO}_{2}$ ( $\left.\mathrm{vol} / \mathrm{vol}\right)$ in humidified air. Incubation temperature was $38.5^{\circ} \mathrm{C}$ unless stated otherwise.

Experiments 4 and 5 were each designed with a 2 $\times 2$ factorial arrangement of treatments to determine whether vitamin E protects two-cell bovine embryos from heat shock. Embryos at the two-cell stage were harvested 28 to $30 \mathrm{~h}$ after insemination and placed in $50-\mu l$ drops. The number of embryos per drop were similar within a replicate. For experiment 4 , there were 13 to 23 embryos per drop, while there were 11 to 21 embryos per drop for experiment 5 . Embryos were preincubated for $5 \mathrm{~h}$ at $38.5^{\circ} \mathrm{C}$ in modified $\mathrm{KSOM}$ containing either vehicle $[0.05 \%(\mathrm{vol} / \mathrm{vol})$ ethanol] or 100 $\mu M$ vitamin $\mathrm{E}$ in $0.05 \%$ (vol/vol) ethanol. Following pre- incubation, embryos were either maintained at $38.5^{\circ} \mathrm{C}$ continuously or exposed to a heat shock of $41^{\circ} \mathrm{C}$ for 9 $\mathrm{h}$ (experiment 4) or $4.5 \mathrm{~h}$ (experiment 5) and $38.5^{\circ} \mathrm{C}$ thereafter. The percentage of embryos developing to the blastocyst stage in each drop was determined on $d$ 8 after insemination. Experiment 4 was replicated 4 times using 114 to 121 embryos/group ( 1 to 2 drops of embryos per treatment in each replicate). Experiment 5 was replicated 4 times using 92 to 137 embryos/group (1 to 2 drops of embryos per treatment in each replicate).

Experiment 6 utilized a $2 \times 2$ factorial arrangement of treatments to determine whether vitamin $\mathrm{E}$ protects bovine embryos at the morula stage from heat shock. Embryos at the morula stage were harvested on $\mathrm{d} 5$ after insemination, placed in 50- $\mu$ l drops (10 to $23 \mathrm{em}$ bryos per drop; the number of embryos per drop were similar for all treatments within a replicate) and treated as for experiment 4 . The percentage of embryos developing to the blastocyst stage in each drop was determined on $\mathrm{d} 8$ after insemination. The experiment was replicated 4 times using 125 to 183 embryos/group ( 1 to 3 drops of embryos per treatment was prepared for each replicate).

\section{Statistical Analyses}

Data were analyzed by least-squares analysis of variance using the general linear models procedure and the mixed models procedure of SAS (SAS, 1989). Initial analysis of the reproductive data for experiments 1 and 2 included the main effects of treatment, parity (primiparous vs multiparous), and season of first breeding (cool season, cows inseminated from September to April; hot season, cows inseminated from May to August) as well as interactions between these terms. Initial analysis of data for experiment 3 included main effects of treatment, parity (primiparous vs. multiparous), season of first breeding (cool season cows inseminated from September to April; hot season cows inseminated from May to August) and the time of the prepartum injection relative to calving (cows injected $>14 \mathrm{~d}$ before expected calving; cows injected $<14 \mathrm{~d}$ and $>8 \mathrm{~d}$ before expected calving; cows injected $<8$ d before expected calving). Nonsignificant terms were subsequently removed from the analysis. Thus, the mathematical model for the final analysis of reproductive data for experiments 1 to 3 included main effects of treatment and parity. The mathematical model for data on milk yield and composition included main effects of treatment, parity, and month of calving, all interactions, and DIM as a covariate. Plasma $\alpha$-tocopherol concentration data were analyzed using main effects of treatment, time of sample collection relative to calving (prepartum, and 1 to 14 , 15 to 28,29 to 35,36 to 42 , and $>42$ d postpartum), 
Table 2. Concentrations of plasma $\alpha$-tocopherol as affected by multiple vitamin E and selenium injections. ${ }^{1}$

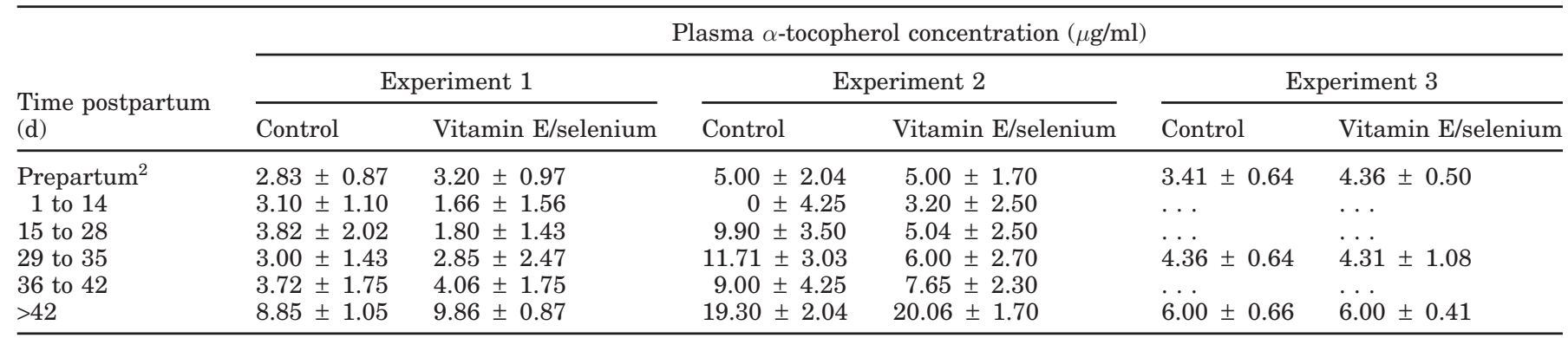

${ }^{1}$ Data represent least-squares means \pm SEM. Differences between treatments (within experiment) were not significant.

${ }^{2}$ Prepartum samples were taken on the day of first vitamin $\mathrm{E}$ and selenium injection.

and cow. Effect of cow was considered a random effect and all other main effects were fixed.

For embryo studies, there was one or more drop per treatment for each replicate and the percentage of embryos developing to the blastocyst stage was calculated for each drop. Percentage data were transformed using the arcsin transformation before analysis. Data were analyzed using main effects of treatment, temperature, and replicate using the general linear models (GLM) procedure of SAS, where replicate (i.e., day of IVF procedure) was considered a fixed variable, and by the mixed models procedure of SAS, where replicate was considered a random variable (SAS, 1989). Probability values were similar for both methods, and probability values reported herein are derived from the analysis by GLM.

\section{RESULTS}

\section{Effect of Multiple Vitamin E and Selenium Injections on Fertility and Milk Yield}

Intramuscular injection of $500 \mathrm{mg}$ vitamin $\mathrm{E}$ and 50 mg Se before calving and at 30 and $80 \mathrm{~d}$ postpartum did not affect plasma $\alpha$-tocopherol concentrations in any of the three experiments (Table 2). In experiment 1 , in which most first inseminations were in the cool season, administration of vitamin $\mathrm{E}$ and selenium did not improve pregnancy rate at first or second service (Table 3). Similarly, treatment did not improve the proportion of cows that became pregnant by $180 \mathrm{~d}$ postpartum. Also, there was no beneficial effect of vitamin $\mathrm{E}$ and selenium on days from calving to first service, number of services by $180 \mathrm{~d}$ postpartum, birth difficulty or predicted 305-d milk yield. Similar results were also obtained for experiment 2 , where most first inseminations were also in the cool season. As shown in Table 4, vitamin $\mathrm{E}$ and selenium injections did not improve pregnancy rate at first service or the proportion of cows that became pregnant by $120 \mathrm{~d}$ postpartum. Vitamin $\mathrm{E}$ and selenium injections did not affect days from calv- ing to first service, number of services by $120 \mathrm{~d}$ postpartum, birth difficulty or any of the milk yield traits examined.

Experiment 3 was conducted with most first inseminations in the hot season. In this experiment, vitamin $\mathrm{E}$ and selenium injection did not affect pregnancy rate at first or second service or at 90,120 , or $150 \mathrm{~d}$ postpartum (Table 5). Also, there was no beneficial effect of vitamin $\mathrm{E}$ and selenium on days from calving to first service, number of services by $120 \mathrm{~d}$ postpartum, birth difficulty, BCS, or any of the milk yield traits examined.

\section{Effects of Vitamin E on Susceptibility of Bovine Embryos to Heat Shock}

In experiment 4, exposure of 2-cell bovine embryos to heat shock of $41^{\circ} \mathrm{C}$ for $9 \mathrm{~h}$ reduced development $(P$ $<0.001$; Fig. 1B) to the blastocyst stage. However, culture of embryos in medium containing $100 \mu M$ vitamin $\mathrm{E}$ did not alter development at 38.5 or $41^{\circ} \mathrm{C}$ nor reduce the deleterious effect of $41^{\circ} \mathrm{C}$ on development. When embryos at the two-cell stage were exposed to a milder heat shock of $41^{\circ} \mathrm{C}$ for $4.5 \mathrm{~h}$ (experiment 5), there was also a deleterious effect of heat shock and no beneficial effect of vitamin $\mathrm{E}$ on development (Figure 1A). In this study, culture of embryos in medium containing 100 $\mu M$ vitamin $\mathrm{E}$ tended to reduce development at $38.5^{\circ} \mathrm{C}$ (treatment $\times$ temperature, $P=0.09$ ). In contrast to the deleterious effect of heat shock on two-cell embryos, exposure of morulae to heat shock of $41^{\circ} \mathrm{C}$ for $9 \mathrm{~h}$ did not decrease development of those morulae to the blastocyst stage (Figure 1C). Culture in medium containing 100 $\mu M$ vitamin $\mathrm{E}$ had no beneficial effect on blastocyst formation at either temperature. For all the three experiments, there was no effect of vitamin $\mathrm{E}$ on the percentage of blastocysts that became expanded or hatched blastocysts (data not shown).

\section{DISCUSSION}

Multiple vitamin $\mathrm{E}$ and selenium injections failed to improve reproductive function or milk yield in lactating 
Table 3. Effect of multiple vitamin $\mathrm{E}$ and selenium administration on reproductive function and milk yield of lactating Holstein cows (experiment 1$)^{1}$

\begin{tabular}{lcc}
\hline Reproductive and milk yield traits & Control & Vitamin E/selenium \\
\hline Birth difficulty & $1.6 \pm 0.08$ & $1.6 \pm 0.08$ \\
Interval from calving to first service, d & $106.0 \pm 2.0$ & $103.2 \pm 2.0$ \\
Pregnant at first service, \% & $31.0 \pm 5.7(40 / 125)$ & $33.2 \pm 5.6(35 / 122)$ \\
Pregnant at second service, $\%^{2}$ & $31.0 \pm 5.0(21 / 68)$ & $26.6 \pm 5.1(23 / 69)$ \\
Pregnant at 180 d postpartum, \% & $61.1 \pm 4.5(74 / 120)$ & $60.0 \pm 4.5(71 / 119)$ \\
Number of services at 180 d postpartum & $2.0 \pm 0.10$ & $2.0 \pm 0.10$ \\
Days in milk, last test day & $293.0 \pm 6.1$ & $272.5 \pm 6.1$ \\
Last test day milk yield, kg & $9972 \pm 121$ & $9903 \pm 118$ \\
Predicted 305-d milk yield, kg & $9635 \pm 156$ & $9322 \pm 153$ \\
\hline
\end{tabular}

${ }^{1}$ Cows were either injected with $500 \mathrm{mg}$ of vitamin $\mathrm{E}$ and $109.5 \mathrm{mg}$ of sodium selenite or placebo at 21 $\mathrm{d}$ before expected calving, 30 and $80 \mathrm{~d}$ postpartum. Data represent least-squares means $\pm \mathrm{SEM}$. There were no significant differences between treatments.

${ }^{2}$ Numbers in parentheses represent number of pregnant cows per number of total cows. Because of multiple variables in the model, reported least squares mean percentages vary slightly from percentages obtained by dividing pregnant cows by total cows.

Table 4. Effect of multiple vitamin $\mathrm{E}$ and selenium administration on reproductive function and milk yield of lactating Holstein cows (experiment 2). ${ }^{1}$

\begin{tabular}{lcc}
\hline Reproductive and milk yield traits & Control & Vitamin E/selenium \\
\hline Birth difficulty & $1.5 \pm 9.0$ & $1.6 \pm 8.5$ \\
Interval from calving to first service, d & $72.6 \pm 2.3$ & $70.2 \pm 2.2$ \\
Pregnant at first service, \% & $17.0 \pm 5.0(9 / 66)$ & $21.1 \pm 4.6(13 / 72)$ \\
Pregnant at 120 d postpartum, \% & $35.8 \pm 6.3(21 / 65)$ & $39.4 \pm 6.0(25 / 71)$ \\
Number of services at 120 d postpartum & $1.8 \pm 0.12$ & $1.7 \pm 0.11$ \\
Days in milk, last test day & $295.1 \pm 7.6$ & $290.6 \pm 8.0$ \\
Last test day milk yield, kg & $7704 \pm 381$ & $7523 \pm 384$ \\
Last test day fat, kg & $259.7 \pm 14.6$ & $261.0 \pm 14.7$ \\
Last test day protein, kg & $243.0 \pm 10.9$ & $240.0 \pm 11.0$ \\
Predicted 305-d milk yield, kg & $7200 \pm 627$ & $6946 \pm 646$ \\
\hline
\end{tabular}

${ }^{1}$ Cows were either injected with $500 \mathrm{mg}$ of vitamin $\mathrm{E}$ and $109.5 \mathrm{mg}$ of sodium selenite or placebo at 21 $\mathrm{d}$ before expected calving, 30 and $80 \mathrm{~d}$ postpartum. Data represent least-squares means $\pm \mathrm{SEM}$. There were no significant differences between treatments.

${ }^{2}$ Numbers in parentheses represent number of pregnant cows/number of total cows. Because of multiple variables in the model, reported least squares mean percentages vary slightly from percentages obtained by dividing pregnant cows by total cows.

Table 5. Effect of multiple vitamin E and selenium administration on reproductive function and milk yield of lactating Holstein cows (experiment 3 ). ${ }^{1}$

\begin{tabular}{lrc}
\hline Reproductive and milk yield traits & Control & Vitamin E/selenium \\
\hline Birth difficulty & $1.3 \pm 5.6$ & $1.4 \pm 6.0$ \\
Interval from calving to first service, d & $92.4 \pm 2.0$ & $88.8 \pm 2.0$ \\
Pregnant at first service, $\%^{2}$ & $26.2 \pm 4.0(31 / 118)$ & $21.0 \pm 4.1(22 / 105)$ \\
Pregnant at second service, \% & $31.0 \pm 5.0(26 / 84)$ & $26.6 \pm 5.1(21 / 79)$ \\
Pregnant at 90 d postpartum, \% & & $14.0 \pm 3.4(15 / 107)$ \\
Pregnant at 120 d postpartum, \% & $2.5 \pm 3.2(20 / 121)$ & $32.0 \pm 4.4(34 / 106)$ \\
Pregnant at 150 d postpartum, \% & $27.1 \pm 4.2(32 / 108)$ & $46.1 \pm 5.0(48 / 104)$ \\
Number of services at 120 d postpartum & $47.4 \pm 4.6(55 / 116)$ & $1.7 \pm 0.11$ \\
Days in milk, last test day & $1.8 \pm 0.12$ & $251.2 \pm 2.5$ \\
Last test day milk yield, kg & $251.0 \pm 2.2$ & $9320 \pm 95$ \\
Last test day fat, kg & $9224 \pm 91$ & $325.8 \pm 3.9$ \\
Last test day protein, kg & $321.0 \pm 3.7$ & $272.2 \pm 2.5$ \\
Predicted 305 milk yield, kg & $267.2 \pm 2.4$ & $10,254 \pm 101$ \\
\hline
\end{tabular}

${ }^{1}$ Cows were either injected with $500 \mathrm{mg}$ of vitamin $\mathrm{E}$ and $109.5 \mathrm{mg}$ of sodium selenite or placebo at 21 $\mathrm{d}$ before expected calving, 30 and $80 \mathrm{~d}$ postpartum. Data represent least-squares means $\pm \mathrm{SEM}$. There were no significant differences between treatments.

${ }^{2}$ Numbers in parentheses represent number of pregnant cows/number of total cows. Because of multiple variables in the model, reported least-squares mean percentages vary slightly from those obtained by dividing pregnant cows by total cows. 


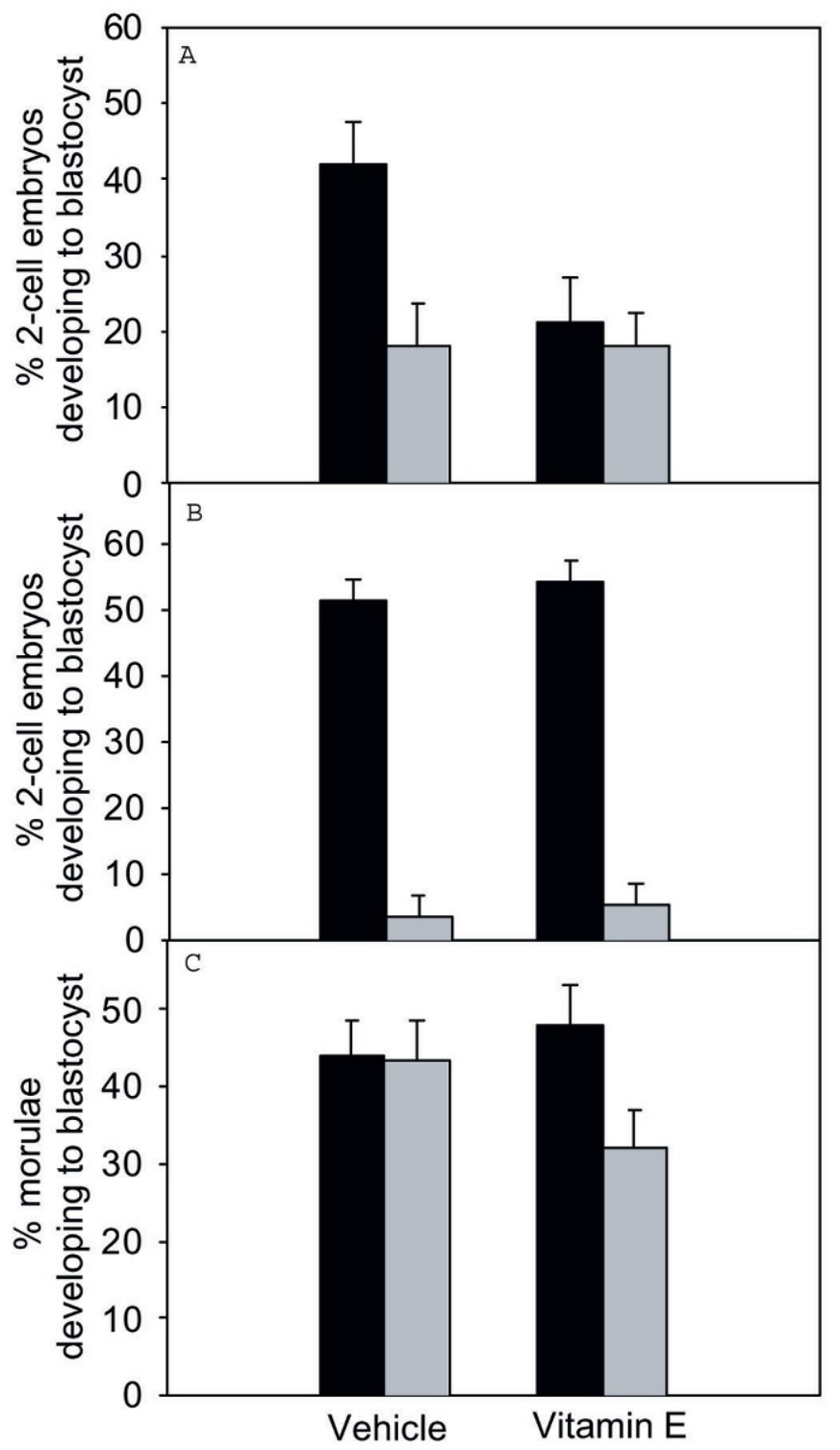

Figure 1. Lack of effect of vitamin $\mathrm{E}$ on development of bovine embryos cultured at $38.5^{\circ} \mathrm{C}$ or exposed to heat shock. Results are least-squares means \pm SEM for two-cell embryos exposed to $41^{\circ} \mathrm{C}$ for $4.5 \mathrm{~h}(\mathrm{~A})$, two-cell embryos exposed to $41^{\circ} \mathrm{C}$ for $9 \mathrm{~h}$ (B), and morulae exposed to $41^{\circ} \mathrm{C}$ for $9 \mathrm{~h}(\mathrm{C})$. Black bars are embryos exposed to $38.5^{\circ} \mathrm{C}$ and grey bars are embryos exposed to $41^{\circ} \mathrm{C}$. Exposure of two-cell embryos to heat shock of $41^{\circ} \mathrm{C}$ for 4.5 (A; $P<0.05$ ) or $9 \mathrm{~h}$ (B; $P<$ 0.001 ) reduced development to the blastocyst stage. The addition of $100 \mu M$ vitamin $\mathrm{E}$ to the culture medium of two-cell embryos did not reduce the deleterious effect of $41^{\circ} \mathrm{C}$ on development. Culture in vitamin $\mathrm{E}$ beginning at the two-cell stage tended to reduce development at $38.5^{\circ} \mathrm{C}$ (treatment $\times$ temperature, $P=0.09$ ) in one experiment (A) but not in the other (B). Heat shock of $41^{\circ} \mathrm{C}$ for $9 \mathrm{~h}$ did not decrease development of morulae to the blastocyst stage and addition of 100 $\mu M$ vitamin $\mathrm{E}$ had no beneficial effect on blastocyst formation at either temperature $(\mathrm{C})$.
Holstein cows. In this respect, results are in agreement with others in which injection or feeding of supplemental vitamin $\mathrm{E}$, selenium, or vitamin $\mathrm{E}$ and selenium failed to affect reproductive function (Schingoethe et al., 1982; Kappel et al., 1984; Ealy et al., 1994) or milk yield (Shin et al., 1999; Baldi et al., 2000). In contrast, other studies have reported a beneficial effect of supplemental vitamin $\mathrm{E}$ or vitamin $\mathrm{E}$ and selenium on fertility (Aréchiga et al., 1994b, 1998b; Baldi et al., 2000) and milk yield (Lacetera et al., 1996). Much of the variation in results among studies may be due to differences in dietary content of vitamin $\mathrm{E}$ and selenium, as well as timing, dosage, and method of administration of supplemental vitamin $\mathrm{E}$ and selenium. For example, the amounts of selenium fed to the prepartum cows in the present study ( 7 to $14 \mathrm{mg} \cdot \mathrm{d}^{-1}$ per cow) were higher than the $0.33 \mathrm{mg} \cdot \mathrm{d}^{-1}$ per cow selenium for two studies in Mexico in which vitamin $\mathrm{E}$ and selenium injections increased fertility (Aréchiga et al., 1994b, 1998b).

The dose of vitamin $\mathrm{E}$ injected into treated cows was less than the amount of vitamin $\mathrm{E}$ supplied in 2-d ration, and this dose may not be effective at altering chronic vitamin E status. In support of this idea is the observation that there was no effect of vitamin $\mathrm{E}$ and selenium injections on plasma concentrations of $\alpha$-tocopherol measured at 2-wk intervals after injection. Similarly, Bass et al. (2000) failed to observe effects of injection of vitamin $\mathrm{E}$ on plasma concentrations of $\alpha$ tocopherol 3 to 4 wk after injection. In contrast, the amount of selenium injected was probably sufficient to affect antioxidant status because intramuscular injection of selenium can increase glutathione peroxidase activity for at least $3 \mathrm{wk}$ (Harrison et al., 1984).

It was reasoned that beneficial effects of vitamin $\mathrm{E}$ and selenium injections would be greater in experiment 3 , where most of the cows were inseminated in hot weather, than for experiments 1 and 2, where most of the cows were inseminated in cool weather. The basis for this hypothesis was the idea that the increase in metabolism when cows are in environments above the upper critical temperature would result in increased oxygen consumption and free radical production. Indeed, heat stress has been reported to deplete plasma antioxidant activity (Harmon et al., 1997). There was, however, no beneficial effect of vitamin $\mathrm{E}$ and selenium in experiment 3 . Pregnancy rates to first service were higher than is typically seen in the summer in Florida, and it is possible that cows in this study were less affected by heat stress than is typically the case because of effective environmental management practices at this farm. In addition, the high dietary content of vitamin $\mathrm{E}$ and selenium in experiment 3 may have negated any beneficial effect of injections of these molecules. 
Other antioxidant treatments were also without effect on fertility of heat-stressed dairy cows including injection of $3000 \mathrm{IU}$ of vitamin $\mathrm{E}$ at the time of AI (Ealy et al., 1994) and multiple injections of $\beta$-carotene (Aréchiga et al., 1998b). Feeding supplemental $\beta$-carotene to heat-stressed cows had only slight effects on reproductive function (Aréchiga et al., 1998a). Thus, it is likely that the failure of vitamin $\mathrm{E}$ and selenium to improve reproductive function during heat stress reflects the fact that antioxidant status is less important for determining reproductive function in the summer than had been hypothesized. Studies indicate that oxygen consumption of lactating cows actually decreases during heat stress (Kibler and Brody, 1956; Sorensen and Weniger, 1987), probably because feed consumption and milk yield is reduced, and such an effect would decrease whole-body, free-radical production.

The present experiments do not support the idea that vitamin $\mathrm{E}$ acts as an effective thermoprotectant or general antioxidant for cultured bovine embryos. Addition of vitamin $\mathrm{E}$ to culture medium did not enhance development of two-cell bovine embryos or morulae at $38.5^{\circ} \mathrm{C}$ or exposed to a heat shock of $41^{\circ} \mathrm{C}$. In mice, vitamin $\mathrm{E}$ reduced the deleterious effect of heat shock on embryonic viability as determined by dye exclusion but did not block the inhibitory effect of heat shock on development to the blastocyst stage (Aréchiga et al., 1994a). Olson and Seidel (2000) observed that vitamin E supplementation during culture of bovine embryos increased embryonic development to the blastocyst stage. Variation between studies may be due to differences in the system for culturing embryos, i.e., in an atmosphere of $20 \%$ oxygen in the present study vs. $5 \%$ oxygen in the study by Olson and Seidel (2000). It is possible that the high oxygen concentration used in the present study resulted in exacerbated free radical production that could not be compensated for by the use of vitamin $\mathrm{E}$ as an antioxidant. Also, embryos in the present study were not exposed to vitamin $\mathrm{E}$ until the two-cell stage, whereas embryos in the earlier study were cultured with vitamin $\mathrm{E}$ beginning at the one-cell stage. The concentration of vitamin $\mathrm{E}$ used in the present experiments, $100 \mu M$, was chosen because it was the concentration used by Olson and Seidel (2000). Possibly, thermoprotective effects of vitamin $\mathrm{E}$ would have been different at other concentrations.

As has been reported earlier (Edwards and Hansen, 1997), embryonic sensitivity to heat shock was reduced as embryos advanced in development. In particular, exposure of two-cell embryos to $41^{\circ} \mathrm{C}$ reduced the proportion of embryos that developed to the blastocyst stage, whereas a similar heat shock had no effect on development of morula to the blastocyst stage. Thus, embryos acquire resistance to elevated temperature as they advance in development.

In summary, the experiments in this study failed to yield evidence of a beneficial effect of supplemental vitamin $\mathrm{E}$ and selenium above estimated requirements on reproduction or milk yield of lactating dairy cows under cool or heat stress conditions or of vitamin $\mathrm{E}$ as an embryonic thermoprotectant or as a culture medium additive for enhancing development of preimplantation embryos in culture. It is concluded that multiple injections of vitamin $\mathrm{E}$ and selenium in the manner tested are unlikely to enhance reproductive or lactational performance of lactating dairy cows receiving dietary requirements of these nutrients.

\section{ACKNOWLEDGMENTS}

The authors thank Schering-Plough Corp. and Harlan Bigbee for donation of MU-SE; Morgan Peltier, Rocío Rivera, Şaban Tekin, Paolete Soto and Gabriel Couto for help in the field; Nancy Wilkinson for help with vitamin E assays; William Rembert for collecting ovaries; Marshall, Alex, and Adam Chernin and employees of Central Beef Packing Co. (Center Hill, FL) for providing ovaries; and Scott A. Randell and Southeastern Semen Services, Lake City, Florida, for donating semen. Special thanks go to employees of the University of Florida Dairy Research Unit, Dale and Connie Sauls and the employees of Condale Dairy, and Don Bennink and employees of North Florida Holstein Dairy, for providing research animals and assistance with animal handling.

\section{REFERENCES}

Ando, M., K. Katagiri, S. Yamamoto, K. Wakamatsu, I. Kawahara, S. Asanuma, M. Usuda, and K. Sasaki. 1997. Age-related effects of heat stress on protective enzymes for peroxides and microsomal monooxygenase in rat liver. Environ. Health Perspect. 105:727-733.

Aréchiga, C. F., A. D. Ealy, and P. J. Hansen. 1994a. Efficacy of vitamin $\mathrm{E}$ and glutathione for thermoprotection of murine morulae. Theriogenology 41:1545-1553.

Aréchiga, C. F., O. Ortiz, and P. J. Hansen. 1994b. Effect of prepartum injection of vitamin $\mathrm{E}$ and selenium on postpartum reproductive function of dairy cattle. Theriogenology 41:1251-1258.

Aréchiga, C. F., C. R. Staples, L. R. McDowell, and P. J. Hansen. 1998a. Effects of timed insemination and supplemental $\beta$-carotene on reproduction and milk yield of dairy cows under heat stress. J. Dairy Sci. 81:390-402.

Aréchiga, C. F., S. Vazquez-Flores, O. Ortíz, J. Hernandez-Cerón, A. Porras, L. R. McDowell, and P. J. Hansen. 1998b. Effect of injection of $\beta$-carotene or vitamin $\mathrm{E}$ and selenium on fertility of lactating dairy cows. Theriogenology 50:65-76.

Arthur, J. R. 2000. The glutathione peroxidases. Cell Mol. Life Sci. 57:1825-1835.

Baldi, A., G. Savoini, L. Pinotti, E. Monfardini, F. Cheli, and V. Dell'Orto. 2000. Effects of vitamin E and different energy sources on vitamin $\mathrm{E}$ status, milk quality and reproduction in transition cows. J. Vet. Med. Ser. A 47:599-608. 
Bass II, R. T., W. S. Swecker Jr., and C. C. Stallings. 2000. Effects of supplemental parenteral administration of vitamin $\mathrm{E}$ and selenium to Jerseys and Holsteins during the nonlactating period. Am. J. Vet. Res. 61:1052-1056.

Berry, E. M., and R. Kohen. 1999. Is the biological antioxidant system integrated and regulated? Med. Hypotheses 53:397-401.

Ealy, A. D., C. F. Arèchiga, D. R. Bray, C. A. Risco, and P. J. Hansen. 1994. Effectiveness of short-term cooling and vitamin $\mathrm{E}$ for alleviation of infertility induced by heat stress in dairy cows. J. Dairy Sci. 77:3601-3607.

Edwards, J. L., and P. J. Hansen. 1997. Differential responses of bovine oocytes and preimplantation embryos to heat shock. Mol. Reprod. Dev. 46:138-145.

Fujitani, Y., K. Kasai, S. Ohtani, K. Nishimura, M. Yamada, and K. Utsumi. 1997. Effect of oxygen concentration and free radicals on in vitro development of in vitro-produced bovine embryos. J. Anim. Sci. 75:483-489.

Fulbert, J. C., and M.-J. Cals. 1992. Les radicaux libres en biologie clinique: origine, rôle pathogène et moyens de défense. Pathol. Biol. 40:66-77.

Griveau, J. F., E. Dumont, P. Renard, J. P. Callegari, and D. Le Lannou. 1995. Reactive oxygen species, lipid peroxidation and enzymatic defense systems in human spermatozoa. J. Reprod. Fertil. 103:17-26.

Harmon, R. J., M. Lu, D. S. Trammell, B. A. Smith, J. N. Spain, and D. Spiers. 1997. Influence of heat stress and calving on antioxidant activity in bovine blood. J. Dairy Sci. 80(Suppl. 1):264. (Abstr).

Harrison, J. H., D. D. Hancock, and H. R. Conrad. 1984. Vitamin E and selenium for reproduction of the dairy cow. J. Dairy Sci. 67:123-132

Kappel, L. C., R. H. Ingraham, E. B. Morgan, J. M. Dixon, L. Zeringue, D. Wilson, and D. K. Babcock. 1984. Selenium concentrations in feeds and effects of treating pregnant Holstein cows with selenium and vitamin $\mathrm{E}$ on blood selenium values and reproductive performance. Am. J. Vet. Res. 45:691-694.

Kibler, H. H., and S. Brody. 1956. Influence of diurnal temperature cycles on heat production and cardiorespiratory activity in Holstein and Jersey cows. Missouri Agric. Stn. Bull. 601.

Lacetera, N., U. Bernabucci, B. Ronchi, and A. Nardone. 1996. Effects of selenium and vitamin $\mathrm{E}$ administration during a late stage of pregnancy on colostrum and milk production in dairy cows, and on passive immunity and growth of their offspring. Am. J. Vet. Res. 57:1776-1780.

Njeru, C. A., L. R. McDowell, N. S. Wilkinson, S. B. Linda, S. N. Williams, and E. L. Lentz. 1992. Serum $\alpha$-tocopherol concentration in sheep after intramuscular injection of DL- $\alpha$-tocopherol. J. Anim. Sci. 70:2562-2567.

Olson, S. E., and G. E. Seidel, Jr. 2000. Culture of in vitro-produced bovine embryos with vitamin $\mathrm{E}$ improves development in vitro and after transfer to recipients. Biol. Reprod. 62:248-252.

Paula-Lopes, F. F., and P. J. Hansen. 2002. Heat shock-induced apoptosis in preimplantation bovine embryos is a developmentally regulated phenomenon. Biol. Reprod. 66:1169-1177.

Pursley, J. R., M. C. Wiltbank, J. S. Stevenson, J. S. Ottobre, H. A. Garverick, and L. L. Anderson. 1997. Pregnancy rates per artificial insemination for cows and heifers inseminated at a synchronized ovulation or synchronized estrus. J. Dairy Sci. 80:295-300.

SAS, 1989. SAS User's Guide. Statistical Analysis System Institute, Inc., Cary, NC.

Schingoethe, D. J., C. A. Kirkbride, I. S. Palmer, M. J. Owens, and W. L. Tucker. 1982. Response of cows consuming adequate selenium to vitamin $\mathrm{E}$ and selenium supplemetation prepartum. J. Dairy Sci. 65:2338-2344.

Shin, H. T., K. H. Chung, S. T. Cha, and T. Rhim. 1999. Effect of different dietary selenium sources on somatic cell counts and selenium in dairy cow milk. Korean J. Anim. Sci. 41:463-470.

Skibba, J. L., A. Stadnicka, J. H. Kalbfleisch, and R. H. Powers. 1989. Effects of hyperthermia on xanthine oxidase activity and glutathione levels in the perfused rat liver. J. Biochem. Toxicol. 4:119-125.

Sorensen, B., and J. Weniger. 1987. Untersuchungen zum Energieumsatz von laktierenden Kuhen unter Warmebelastung. 2. Ergebnisse zum Energieumsatz in verschiedenen Abschnitten der Laktation sowie Beziehungen zu weiteren thermoregulatorisch relevanten Funktionsparametern. Zuchtungskunde 59:307-315.

Trinder, N., C. D. Woodhouse, and C. P. Renton. 1969. The effect of vitamin $\mathrm{E}$ on the incidence of retained placentae in dairy cows. Vet. Rec. 85:550-553.

Wang, X., and P. J. Quinn. 2000. The location and function of vitamin $\mathrm{E}$ in membranes (review). Mol. Membr. Biol. 17:143-156.

Yang, H. W., K. J. Hwang, H. C. Kwon, H. S. Kim, K. W. Choi, and K. S. Oh. 1998. Detection of reactive oxygen species (ROS) and apoptosis in human fragmented embryos. Hum. Reprod. 13:998-1002. 